\title{
MAPPING WETLANDS OF DONGTING LAKE IN CHINA USING LANDSAT AND SENTINEL-1 TIME SERIES AT 30M
}

\author{
Liwei Xing ${ }^{1,2}$, Xinming Tang ${ }^{1 *}$, Huabin Wang ${ }^{1}$, Wenfeng Fan ${ }^{1}$, Xinyuan Gao ${ }^{1}$

\begin{abstract}
${ }^{1}$ Satellite Surveying and Mapping Application Center, National Administration of Surveying, Mapping and Geoinformation, No.1 Baishengcun, Zizhuyuan Road, Haidian District, Beijing, 100048, P.R. China - phdxingliwei@163.com, tangxinming99@qq.com, whb@sasmac.cn, fan88628643@qq.com, 969520377@qq.com

${ }^{2}$ State Key Laboratory Incubation Base of Urban Environmental Processes and Digital Simulation, Capital Normal University, No.105 Xisanhuan North Road, Haidian District, Beijing, 100048, P.R. China
\end{abstract}

Commission III, WG III/1

KEY WORDS: Wetlands, Landsat, Sentinel-1, Time series, Dongting Lake, SVM

\begin{abstract}
:
Mapping and monitoring wetlands of Dongting lake using optical sensor data has been limited by cloud cover, and open access Sentinal-1 C-band data could provide cloud-free SAR images with both have high spatial and temporal resolution, which offer new opportunities for monitoring wetlands. In this study, we combined optical data and SAR data to map wetland of Dongting Lake reserves in 2016. Firstly, we generated two monthly composited Landsat land surface reflectance, NDVI, NDWI, TC-Wetness time series and Sentinel-1 (backscattering coefficient for VH and VV) time series. Secondly, we derived surface water body with two monthly frequencies based on the threshold method using the Sentinel-1 time series. Then the permanent water and seasonal water were separated by the submergence ratio. Other land cover types were identified based on SVM classifier using Landsat time series. Results showed that (1) the overall accuracies and kappa coefficients were above $86.6 \%$ and 0.8 . (3) Natural wetlands including permanent water body (14.8\%), seasonal water body (34.6\%), and permanent marshes (10.9\%) were the main land cover types, accounting for $60.3 \%$ of the three wetland reserves. Human-made wetlands, such as rice fields, accounted $34.3 \%$ of the total area. Generally, this study proposed a new flowchart for wetlands mapping in Dongting lake by combining multi-source remote sensing data, and the use of the two-monthly composited optical time series effectively made up the missing data due to the clouds and increased the possibility of precise wetlands classification.
\end{abstract}

\section{INTRODUCTION}

Wetlands, as one of the most critical ecosystems, can provide a series of ecological services, such as conserving biological diversity, controlling runoff volume, minimizing sediment loss and purifying surface water (Bwangoy et al. 2010). However, wetlands have been damaged and threatened by the urban expansion and the global climate changes (Brinson and Malvárez 2002; Niu et al. 2009). To understand wetlands functions and monitor wetlands response to natural and human activities, accurate wetland mapping is significant importance.

Remote sensing imagery has been widely used to monitor wetlands as satellites could monitor land surface efficient and timely observation (Ozesmi and Bauer 2002; Töyrä and Pietroniro 2005; Rebelo et al. 2009). Most existing studies map and monitor wetlands using single-date imagery, but the singledate observations ignore the seasonal variations of wetlands (Kashaigili et al. 2006; Lee and Yeh 2009; Gong et al. 2010; Zhang et al. 2011; Han et al. 2015). To avoid this limitation, satellite imagery time series were used to identify seasonal wetlands as the image time series have potential to monitor plant phenological characteristics and season dynamic of water surface. Low-resolution data with high temporal resolution, such as Moderate-resolution Imaging Spectroradiometer (MODIS) images, was the primary data (Galford et al. 2008; Lhermitte et al. 2011; Nguyen et al. 2012; Sun et al. 2014). However, MODIS data cannot precisely identify detail of the wetlands and smaller wetlands because of the relatively low coarse resolution. While images at better spatial resolution, such as Landsat data, always have low temporal frequency and irregular image times series because of clouds.

Synthetic Aperture Radar (SAR) microwaves can penetrate clouds and independent on illumination, but have been less used at large scale due to the high costs and intensive processing requirements, such as TerraSAR-X X-band), COSMO-SkyMed (X-band) and RADARSAT-2 (C-band) (Gstaiger et al., 2012; Pulvirenti et al., 2011). The Sentinel-1 satellite which is launched recently could provide free-available SAR data at high temporal frequency (six days considering Sentinel-1A and B at the Equator) and the high spatial resolution (Torres et al., 2012), these data could contribute to accurate wetlands mapping and inter-annual variation monitoring.

Dongting lake, the second largest lake freshwater lake in China, is famous for its rapid seasonal changes because it is in inundation extents of the middle reach of the Yangtze River, and it is also the lake most affected by the Three Gorges Project (Ding \& Li, 2011, Li et al., 2011). Considerable research has focused on mapping and monitoring wetlands at Dongting Lake using time series data (Hu et al., 2015). But these researches always used MODIS or ENVISAT ASAR data at $150 \mathrm{~m}, 250 \mathrm{~m}$, and $500 \mathrm{~m}$ or lower spatial resolution, the wetlands classification accuracy is low due the mixed pixels. Therefore, it is urgently need to map the wetlands of Dongting lake using

\footnotetext{
* Corresponding author
} 
satellite series time at high spatial resolution. Therefore, the main objectives of this study are to (1) to create optical and SAR time series using Landsat 7, Landsat 8 and Sentinel-1 data separately with two-monthly composition strategy for 2016; (2) to derive surface water body based on threshold using the Sentinal-1 time series; (3) to identify the other land cover types based on SVM classifier using Landsat time series; (4) to analyse the distribution characteristics of different wetland types in three wetland reserves of Dongting lake.

\section{STUDY AREA AND DATA SETS}

\subsection{Study area}

Dongting Lake includes three national wetland nature reserves: the East Dongting lake reserve, the South Dongting lake reserve, and the West Dongting lake reserve (Figure 1), which were included in the List of Ramsar Sites in 1992 and 2002 (http://www.ramsar.org/wetland/china). The main land cover types in the study region include permanent water body, seasonal water body, marshes, rice fields, forest and impervious surface. The classification system used a twotier hierarchical structure. Water include permanent and seasonal water body in level two, which were not showed in Table 1 due to the method for identifying water. The number of training and validation samples for each land cover was showed in Table 1.

\begin{tabular}{|c|c|c|c|c|}
\hline $\begin{array}{l}\text { Level } \\
\text { one }\end{array}$ & Level two & Month & $\begin{array}{l}\text { training } \\
\text { samples }\end{array}$ & $\begin{array}{l}\text { validation } \\
\text { samples }\end{array}$ \\
\hline water & & $\begin{array}{l}\text { January- } \\
\text { February } \\
\text { March-April } \\
\text { May-June } \\
\text { July-August } \\
\text { September- } \\
\text { October } \\
\text { November- } \\
\text { December }\end{array}$ & $\begin{array}{l}141 \\
131 \\
190 \\
203 \\
133 \\
\\
138\end{array}$ & $\begin{array}{l}152 \\
145 \\
201 \\
216 \\
142 \\
\\
149\end{array}$ \\
\hline $\begin{array}{l}\text { non- } \\
\text { water }\end{array}$ & $\begin{array}{l}\text { marshes } \\
\text { rice fields } \\
\text { forest } \\
\text { impervious } \\
\text { surface }\end{array}$ & $\begin{array}{l}\text { January- } \\
\text { December } \\
\text { January- } \\
\text { December } \\
\text { January- } \\
\text { December } \\
\text { January- } \\
\text { December }\end{array}$ & $\begin{array}{l}120 \\
491 \\
337 \\
110\end{array}$ & $\begin{array}{l}132 \\
530 \\
391 \\
119\end{array}$ \\
\hline
\end{tabular}

Table 1. The Land covers classification system

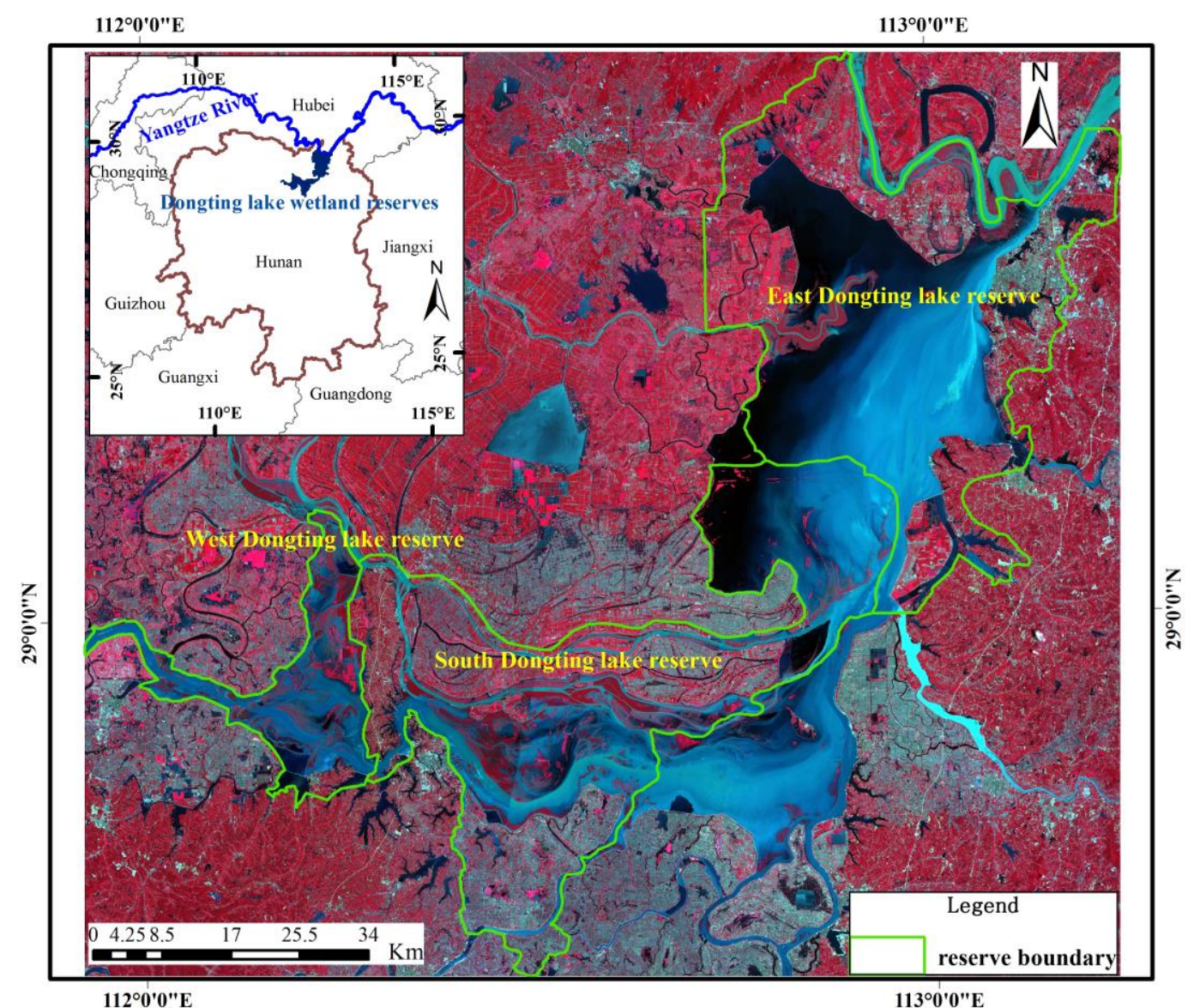

Figure 1. Location of study area

\subsection{Datasets}

Landsat 7 ETM+ and Landsat 8 OLI land surface reflectance (SR) product (path/row: $123 / 40$ and 124/40) with cloud cover lower than $60 \%$ were acquired in 2016. The data were download from the United States Geological Survey (USGS) (https://earthexplorer.usgs.gov/). Then Landsat $30 \mathrm{~m}$ land surface reflectance were two-monthly composited using the median value of all pixels at the same location during the two months. Three additional indices, the Normalized Difference Vegetation Index (NDVI) (Tucker, 1979), the Normalized 
Difference Water Index (NDWI) (Zarco-Tejada et al., 2003) and Tasselled Cap Transformation Wetness Index (TC-Wetness) (Li et al., 2016) were derived from the Landsat reflectance data with two monthly frequencies.

Sentiel-1A satellite provide C-Band image in singular and dual polarization. The revisit time is twelve days. We used Level-1 Ground Range Detected (GRD) images in the IW mode with dual-polarization (VH /VV) (Cazals et al., 2016). The Sentinal1 data were resampled to $30 \mathrm{~m}$ resolution using the nearest neighbour method to make them spatially consistent with the Landsat data. In our study, the backscattering coefficient for $\mathrm{VH}$ and VV polarizations obtained using Sentinel Application Platform software (SNAP) were utilized to map the surface water of Dongting lake wetland reserves. The backscattering coefficient were also composited at two monthly spatial resolution.

\section{METHOD}

The flowchart of this study was showed in Figure 2. Firstly, we generated two monthly composited Landsat time series data (SR, NDVI, NDWI and TC-Wetness) and Sentinal-1 time series. Secondly, Sentinel-1 time series backscattering coefficient for $\mathrm{VH}$ and VV polarization were used to identify water body using the threshold method. Then permanent and seasonal water were separated by the submergence ratio. And finally, the non-water land covers were identified using Landsat time series based on SVM classifier.

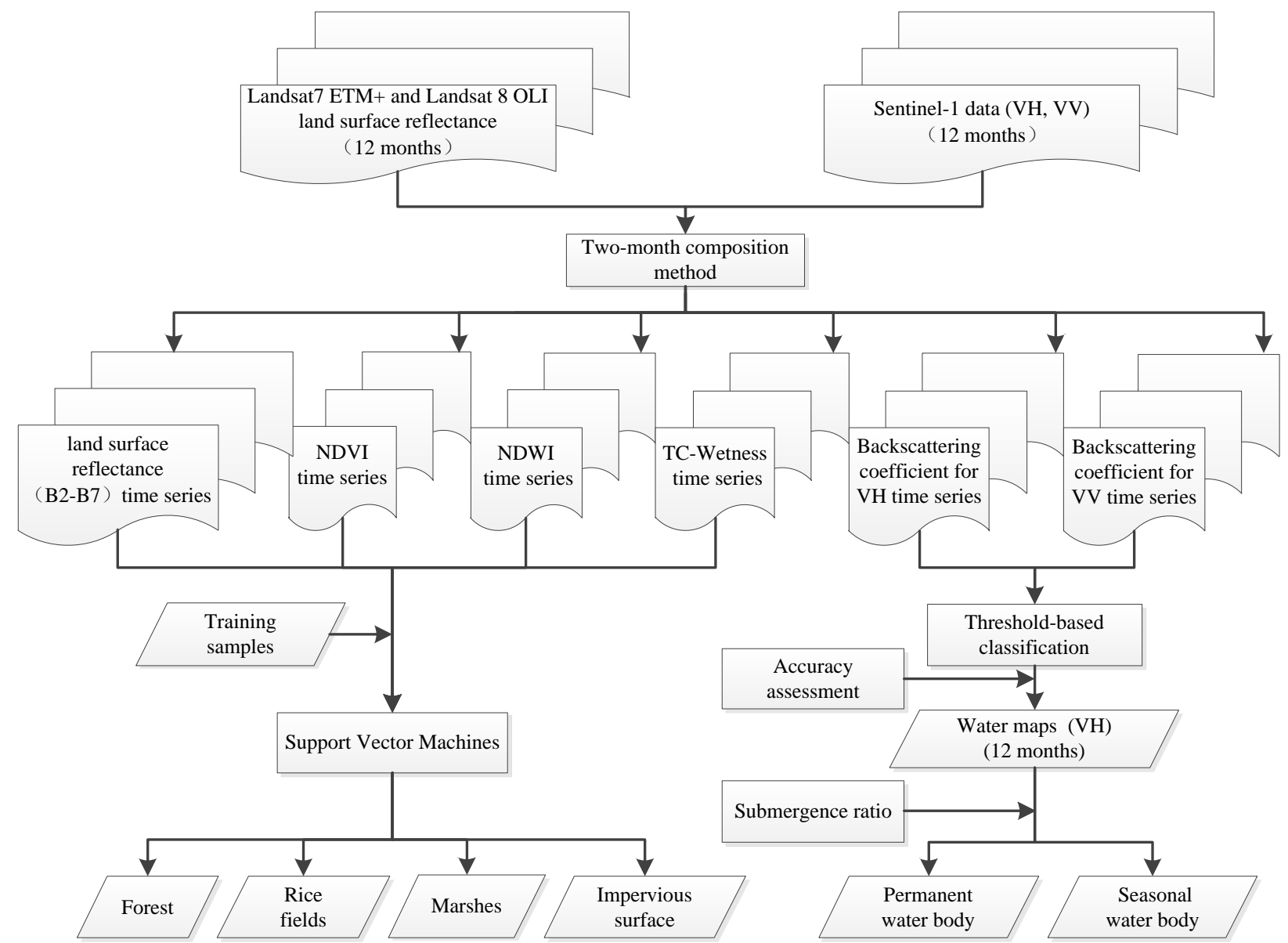

Figure 2. Flowchart of the methodology followed in the study

\subsection{Threshold-based classification}

The threshold method with the characteristics of efficient and simple was widely used in mapping water. The key of threshold method is determining the threshold. There are many methods used to determine the threshold, such as the maximum entropy method (Kapur et al., 1985), the minimum interclass variance method (Radhika et al., 2009) and the Otsu method (Otsu, 1979). However, these methods are always complex and timeconsuming. Empirical methods with the characteristic of samples were considered as the most commonly used method to determine the threshold, which may lead to variable accuracy due to the operator's subjective evaluation. In our study, a simple and efficient method was used to determine the threshold.
The method was based on the water and non-water training samples. The water and non-water training samples presented obvious normal distribution. The valve in the trough of the normal distribution probability density functions of the water and non-water training samples was considered as the threshold. The thresholds for every two monthly were showed in Table 2 .

\begin{tabular}{|l|l|l|}
\hline Month & $\mathrm{VH}(\mathrm{dB})$ & $\mathrm{VV}(\mathrm{dB})$ \\
January-February & -22.21 & -15.68 \\
March-April & -21.76 & -16.43 \\
May-June & -22.49 & -17.00 \\
July-August & -20.62 & -14.54 \\
September-October & -21.29 & -16.85 \\
November-December & -21.00 & -14.98 \\
\hline
\end{tabular}

Table 2. Wetlands The threshold for VH or VV backscattering coefficient for every two monthly 


\subsection{Permanent and Seasonal Water Identification method}

To understand the characteristic and influences of the water body dynamic changes in Dongting lake, the submergence ratio was calculated as the following equation for each pixel:

$$
\delta=\frac{n}{N} \times 100 \%
$$

where $\delta$ represents the submergence ratio; $\mathrm{n}$ represents the number of inundations observed by Sentinal-1A at two monthly frequency in a year; $\mathrm{N}$ represents the number of total observations times of Sentinal-1A (6 in our study). The permanent water body was flooded the entire year $(\delta=1)$. The seasonal water body was flooded at least one time in a year $(0<\delta<1)$.

\subsection{Support Vector Machine}

Support Vector Machine classifier derived from statistical learning theory. Some researches have showed that SVM can obtain more accurate classification results than other methods, such as the maximum likelihood classification method and decision tree. In our study, we used a SVM classifier to map non-water of Dongting lake wetland reserves. The widely used radial basis function (RBF) kernel was selected and performed using ENVI ver.5.3 software. The best kernel parameter $\gamma$ and a regularization parameter $\mathrm{C}$ (cost) were set to $(100,0.125)$ to train the SVM in practice.

\section{RESULT AND DISCUSSION}

\subsection{Classification Accuracy}

In this study, the overall accuracy (OA), producer's accuracy (PA), user's accuracy (UA), and Kappa coefficient were used to assess the classification accuracy. By comparison, the $\mathrm{VH}$ backscattering coefficient gained higher accuracies of water and non-water classification than the VV backscattering coefficient. The water and non-water classification results were obtained from the VH backscattering coefficient. Then the permanent water and seasonal water were separated by the submergence ratio. Figure 3 showed the wetlands classification result. The $\mathrm{OA}$ and Kappa coefficient were $86.6 \%$ and 0.8 In addition, PAs and UAs of 6 land cover types were all above $81 \%$ (Table 3 ).

\begin{tabular}{|l|l|l|}
\hline Landcover & PA (\%) & UA $(\%)$ \\
\hline permanent water body & 91.15 & 88.03 \\
Seasonal water body & 89.87 & 87.12 \\
marshes & 81.16 & 81.75 \\
rice fields & 87.92 & 87.27 \\
forest & 84.77 & 87.66 \\
impervious surface & 84.68 & 84.00 \\
\hline
\end{tabular}

Table 3. Wetlands classification accuracy of Dongting lake

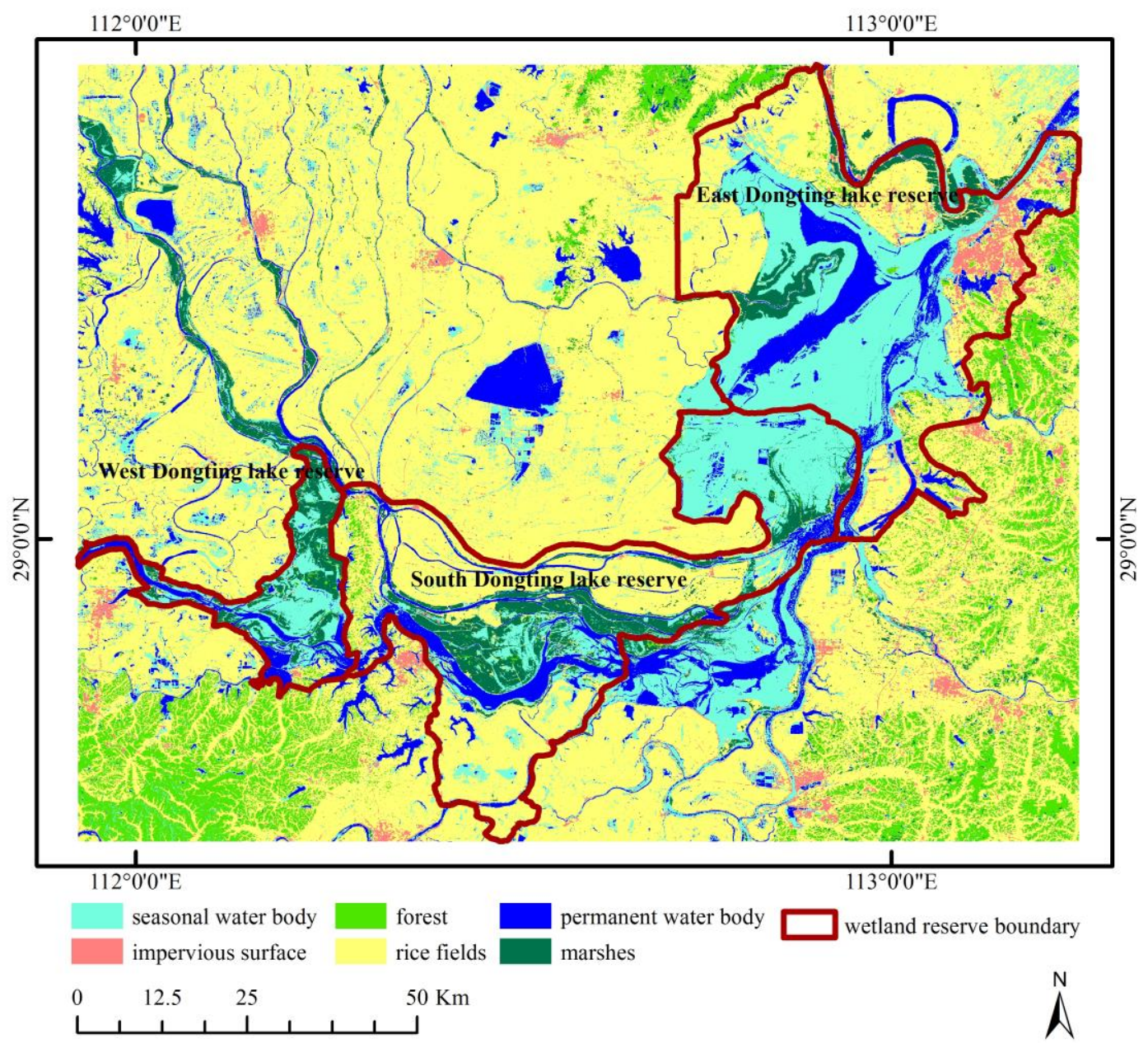

Figure 3. Classification result of Dongting lake in 2016 


\subsection{Area Analysis}

The total wetland area of the three Dongting lake reserves is $3649.5 \mathrm{~km}^{2}$ in 2016, accounting for $94.6 \%$ of the total reserves area. Natural wetlands including permanent water body (14.8\%), seasonal water body $(34.6 \%)$, and marshes $(10.9 \%)$ were the main land cover types, accounting for $60.3 \%$ of the total area of the three reserves. Human-made wetlands, such as rice fields, accounted $34.3 \%$ of the total area. The permanent water body and seasonal water body were both mainly distributed in the East Dongting lake reserve and South Dongting lake reserve (Figure 4). The seasonal water body was generally distributed beside the permanent water body, and these regions should be taken more attention due to the risk of flooding. marshes and rice fields were mainly distributed in the South Dongting lake reserve (Figure 4).

There were some differences in the spatial characteristics of these three reserves. The wetland acreage are $1698.3 \mathrm{~km}^{2}$, $1612.1 \mathrm{~km}^{2}$ and $339.2 \mathrm{~km}^{2}$ in East Dongting lake reserve, South Dongting lake reserve and West Dongting lake, respectively. In the East Dongting lake reserve and West Dongting lake reserve, the seasonal water body occupied the largest area. However, rice fields accounted for the largest surface area in South Dongting lake reserve.

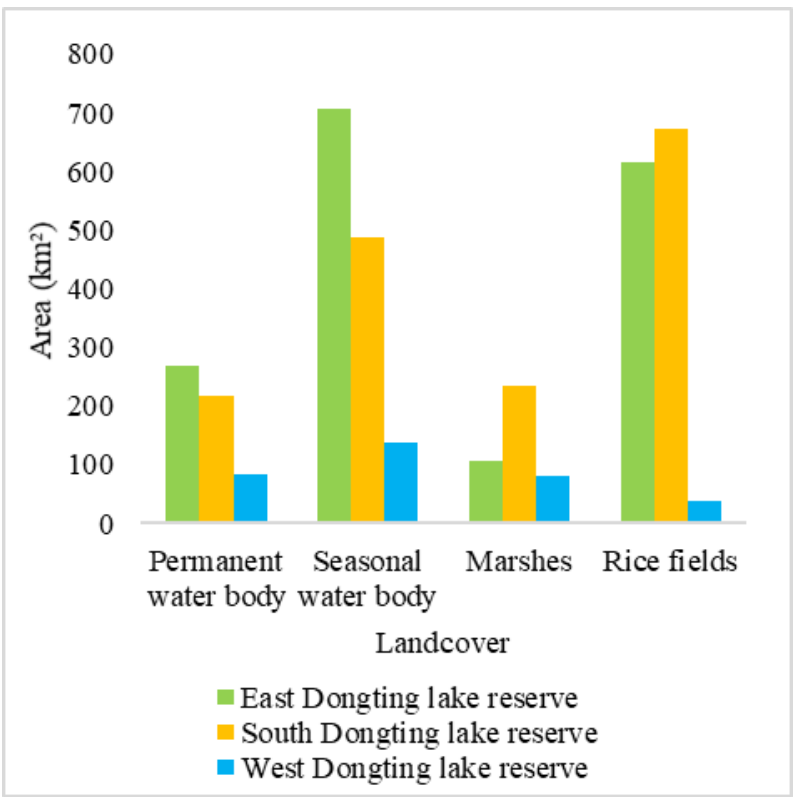

Figure 4. Area statistical results for different wetland types

\section{CONCLUSION}

This study combined multi-source remote sensing data, twomonths composited Landsat time series data (SR, NDVI, NDWI and TC-Wetness) and Sentinal-1 time series data, to identify wetlands of the three Dongting lake reserves. The main conclusions are as follows: (1) the OA and Kappa coefficient were $86.6 \%$ and 0.8 . In addition, PAs and UAs of 6 land cover types were all above $81 \%$. (2) The total wetland area of the three Dongting lake reserves is $3649.5 \mathrm{~km}^{2}$ in 2016 . Natural wetlands accounted for $60.3 \%$ of the total area of the three Dongting lake reserves, and human-made wetland accounted for $34.3 \%$ of the total area. This study proposed a new flowchart for wetlands mapping. And the use of the two-monthly composited optical time series could not only effectively made up the missing data but also increased the possibility of accurate wetland mapping.

\section{ACKNOWLEDGEMENTS (OPTIONAL)}

This research was funded by the National Key Research and Development Program of China (2016YFB0501403).

\section{REFERENCES}

Brinson, M. M., and Malvárez, A. I., 2002. Temperate freshwater wetlands: types, status, and threats. Environmental Conservation 29(02), 115-133. https://doi.org/10.1017/S0376892902000085

Bwangoy, J.-R. B., Hansen, M. C., Roy, D. P., De Grandi, G., and Justice, C. O., 2010. Wetland mapping in the Congo Basin using optical and radar remotely sensed data and derived topographical indices. Remote Sensing of Environment 114(1), 73-86. https://doi.org/10.1016/j.rse.2009.08.004

Cazals C., Rapinel S., Frison P. L., et al. 2016. Mapping and characterization of hydrological dynamics in a coastal marsh using high temporal resolution Sentinel-1a images. Remote Sensing 8(7): 570. https://doi.org/10.3390/rs8070570

Ding X., Li X., 2011. Monitoring of the water-area variations of Lake Dongting in China with ENVISAT ASAR images. International Journal of Applied Earth Observation and Geoinformation13(6):

https://doi.org/10.1016/j.jag.2011.06.009

Galford, G. L., Mustard, J. F., Melillo, J., Gendrin, A., Cerri, C. C., and Cerri, C.E. P., 2008. Wavelet analysis of MODIS time series to detect expansion and intensification of row-crop agriculture in Brazil. Remote Sensing of Environment 112(2), 576-587. https://doi.org/10.1016/J.RSE.2007.05.017

Gong, P., Niu, Z., Cheng,X., Zhao,K., Zhou,D.,Guo, J., Liang, L.,Wang,X., Li, D., and Huang, H., 2010. China's wetland change (1990-2000) determined by remote sensing. Science China. Earth Sciences 53(7), 1036-1042. https://doi.org/10.1007/S11430-010-4002-3

Gstaiger V., Huth J., Gebhardt S., et al., 2012. Multi-sensoral and automated derivation of inundated areas using TerraSAR-X and ENVISAT ASAR data. International journal of remote sensing 33(22): 7291-7304. https://doi.org/10.1080/01431161.2012.700421

Guo, Q., Kelly, M., and Graham, C. H., 2005. Support vector machines for predicting distribution of Sudden Oak Death in California. Ecological Modelling 182(1), 75-90. https://doi.org/10.1016/J.ECOLMODEL.2004.07.012

Han, X., Chen, X., and Feng, L., 2015. Four decades of winter wetland changes in Poyang Lake based on Landsat observations between 1973 and 2013. Remote Sensing of Environment 156, 426-437. https://doi.org/10.1016/J.RSE.2014.10.003

Hoang, T. H., Lock, K., Mouton, A., and Goethals, P. L. M., 2010. Application of classification trees and support vector machines to model the presence of macroinvertebrates in rivers in Vietnam. Ecological Informatics 5(2), 140-146. https://doi.org/10.1016/J.ECOINF.2009.12.001

Hu Y., Huang J., Du Y., et al., 2015. Monitoring spatial and temporal dynamics of flood regimes and their relation to wetland landscape patterns in Dongting Lake from MODIS time-series imagery. Remote Sensing 7(6): 7494-7520. https://doi.org/10.3390/rs70607494

Kapur JN, Sahoo PK, Wong A K C., 1985. A new method for gray-level picture thresholding using the entropy of the histogram. Computer vision, graphics, and image processing 29(3): 273-285. https://doi.org/10.1016/s0734-189x(85)901562 
Kashaigili, J. J., Mbilinyi, B. P., Mccartney, M., and Mwanuzi, F. L., 2006. Dynamics of Usangu Plains wetlands: use of remote sensing and GIS as management decision tools. Physics and Chemistry of the Earth 31(15-16), 967-975. https://doi.org/10.1016/J.PCE.2006.08.007

Lee, T. M., and Yeh, H. C., 2009. Applying remote sensing techniques to monitor shifting wetland vegetation: a case study of Danshui River estuary mangrove communities, Taiwan. Ecological Engineering 35(4), 487-496. https://doi.org/10.1016/J.ECOLENG.2008.01.007

Lhermitte, S., Verbesselt, J., Verstraeten, W. W., and Coppin, P., 2011. A comparison of time series similarity measures for classification and change detection of ecosystem dynamics. Remote Sensing of Environment 115(12), 3129-3152. https://doi.org/10.1016/J.RSE.2011.06.020

Li B., Ti C., Yan X., 2016. Study of derivation of tasseled cap transformation for Landsat 8 OLI images, Science of Surveying and Mapping, 41, 102-107. (In Chinese)

Li J., Dai Y., Ou C., et al., 2011. Effects of store water application of the three gorges reservoir on Yangtze River on water and sediment characteristics in the Dongting Lake. J. Soil Water Conserv 25(15):215-219. (In Chinese)

Nguyen, T. T. H., De Bie, C. A. J. M., Ali, A., Smaling, E. M. A., and Chu, T. H., 2012. Mapping the irrigated rice cropping patterns of the Mekong Delta, Vietnam, through hyper-temporal SPOT NDVI image analysis. International Journal of Remote Sensing 33(2), 415-434. https://doi.org/10.1080/01431161.2010.532826

Niu, Z., Gong, P., Cheng, X., Guo, J., Wang, L., Huang, H., Shen, S., Wu, Y., Wang, X., and Wang, X. (2009). Geographical characteristics of China's wetlands derived from remotely sensed data. Science in China -D. Earth Science 52(6), 723-738. d https://doi.org/10.1007/S11430-009-0075-2

Otsu N., 1979. A threshold selection method from gray-level histograms. IEEE transactions on systems, man, and cybernetics 9(1): 62-66. https://doi.org/10.1109/tsmc.1979.4310076.

Ozesmi, S. L., and Bauer, M. E., 2002. Satellite remote sensing of wetlands. Wetlands Ecology and Management 10(5), 381402. https://doi.org/10.1023/A:1020908432489

Pulvirenti L., Pierdicca N., Chini M., et al., 2011. An algorithm for operational flood mapping from Synthetic Aperture Radar (SAR) data using fuzzy logic. Natural Hazards and Earth System Sciences 11(2): 529. https://doi.org/10.5194/nhess-11529-2011

Radhika K. R., Sekhar G. N., Venkatesha M. K., 2009. Pattern recognition techniques in on-line hand written signature verification-A survey. Multimedia Computing and Systems, 2009. ICMCS'09. International Conference on. IEEE 216-221. https://doi.org/10.1109/mmcs.2009.5256701

Rebelo, L. M., Finlayson, C. M., and Nagabhatla, N., 2009. Remote sensing and GIS for wetland inventory, mapping and change analysis. Journal of Environmental Management 90(7), 2144-2153. https://doi.org/10.1016/J.JENVMAN.2007.06.027 Sun, F., Zhao, Y., Gong, P., Ma, R., and Dai, Y., 2014. Monitoring dynamic changes of global land cover types: fluctuations of major lakes in China every 8 days during 20002010. Chinese Science Bulletin 59(2), 171-189. https://doi.org/10.1007/S11434-013-0045-0

Torres R., Snoeij P., Geudtner D., et al., 2012. GMES Sentinel1 mission. Remote Sensing of Environment 120: 9-24. https://doi.org/10.1016/j.rse.2011.05.028

Töyrä, J., and Pietroniro, A., 2005. Towards operational monitoring of a northern wetland using geomatics-based techniques. Remote Sensing of Environment 97(2), 174-191. https://doi.org/10.1016/J.RSE.2005.03.012
Tucker C. J., 1979. Red and photographic infrared linear combinations for monitoring vegetation, Remote sensing of Environment 8(2): 127-150. https://doi.org/10.1016/00344257(79)90013-0

Zarco-Tejada P. J., Rueda C. A., and Ustin S. L., 2003. Water content estimation in vegetation with MODIS reflectance data and model inversion methods. Remote Sensing of Environment 85(1), 109-124. https://doi.org/10.1016/S0034-4257(02)001979

Zhang, Y., Lu, D., Yang, B., Sun, C., and Sun, M., 2011. Coastal wetland vegetation classification with a Landsat Thematic Mapper image. International Journal of Remote Sensing 32(2), 545-561. https://doi.org/10.1080/01431160903475241 